Andrea Vaona, Guido Ascari

Regional inflation persistence : evidence from Italy

Quaderno N. 08-07

Decanato della Facoltà di Scienze economiche

Via G. Buffi, $13 \mathrm{CH}-6900$ Lugano 


\title{
Regional Inflation Persistence: Evidence from Italy ${ }^{\S}$
}

\author{
Andrea Vaona \\ Corresponding Author \\ Institute for Economic Research, University of Lugano \\ and \\ Kiel Institute for the World Economy \\ Via Maderno 24 \\ CP4361 \\ CH-6904 Lugano \\ Switzerland \\ Tel.: +41586664116 \\ Fax.: +41586664662 \\ E-mail: andrea.vaona@lu.unisi.ch

Guido Ascari
University of Pavia
Department of Economics and Quantitative Methods
University of Pavia
Via S. Felice 5
27100 Pavia
Italy
Tel.:+390382 986211
Fax: +390382304226
E-mail: gascari@eco.unipv.it

$\S$ The authors would like to thank for helpful comments Eckhardt Bode, Stefano Schiavo, Jean-Pierre Danthine, Stefan Gerlach, Elmar Mertens and the participants to the seminars of the $3^{\text {rd }}$ October 2006 at the University of Pavia and of the $27^{\text {th }}$ March 2008 at the Annual Meeting of the Swiss Society of Economics and Statistics held by the University of Lausanne. Fabiano Schivardi and Eliana Viviano kindly provided the data regarding the large store floor space over resident population in 1999. The usual disclaimer applies. 


\title{
Regional Inflation Persistence: Evidence from Italy
}

\begin{abstract}
Regional patterns of inflation persistence have received attention only at a very coarse level of territorial disaggregation, that of EMU member states. However economic disparities within EMU member states are an equally important policy issue. This paper considers a country with a large regional divide, i.e., Italy, at a fine level of territorial disaggregation (NUTS3). Our results show that economically backward regions display greater inflation persistence. Moreover, we show that higher persistence is linked to a lower degree of competitiveness in the retail sector.
\end{abstract}

Keywords: inflation persistence, retail sector, regions JEL Codes: E0, E30, R0, R10. 


\section{Introduction}

Inflation persistence has become one of the central issues regarding the modelling of the inflation process. Indeed, the degree of inflation persistence is crucial for monetary policy, since if the inflation process is less persistent, the task of monetary policy is easier in terms both of sacrifice ratio and of controlling inflation fluctuations around a given target.

By now quite a large literature investigated the nature of the inflation process. First, some papers explore the nature of inflation persistence across countries (e.g., Benigno and Lopez-Salido, 2006), and also across sectors looking at different levels of disaggregation. The main conclusions (see, e.g., Lünnemann and Mathä, 2004 and Cecchetti and Debelle, 2006) are: (i) once the estimation allows for shifts in the mean, inflation persistence is much lower than previously believed; (ii) inflation persistence differs across sectors. Second, the ECB launched a big research project called the Inflation Persistence Network, in order to better understand the pricing behaviour of the single firms, and what is the impact of aggregating these different behaviours on the persistence of the aggregate inflation series. The main results are summarized in Altissimo et al. (2006) (see also, Dhyne et al., 2005). Moreover, Altissimo et al. (2007) show that the aggregate series inherit the properties of their most persistent component, thus justifying the importance to look at different sectoral prices. The same argument, obviously, should also hold when one aggregates geographically, that is, across regions within the same country rather than across sectors.

However, surprisingly enough, only few papers investigates the difference in the inflation process at a regional level. Cecchetti et al. (2002) analyse regional US price data to focus on deviations from PPP across the US and the dynamics of relative prices across regions. Beck and Weber (2005a,b) study inflation rate dispersion across US, Japan, Canada and EMU regions and investigate the issue of convergence of regional inflation rates using distribution dynamics methodology. Busetti et al. (2006) consider the same issue on Italian regional data, but with a different methodology. Beck et al. (2006) use country specific factors as well as idiosyncratic regional components to examine the causes of the inflation dispersion across EMU regions. 
None of the above papers, however, focuses on regional inflation persistence, that is, on the difference between inflation persistence across regions. The implications of regional, rather than sectoral, differences in inflation persistence for the functioning of monetary policy is thus rather limited as it stops at a very coarse level, that of EMU member states. This limitation should not be understated, since differences in regional inflation persistence are evidently as much important as differences in sectoral inflation persistence. As wide regional disparities exist within EMU member states, a common monetary policy should take them into account. Indeed, Benigno (2004) showed that central banks should overweight, within their target index, regions with stickier price developments and underweight more flexible regions, in order to avoid that the former ones bear a disproportionate part of the adjustment process following a monetary shock. Suppose that more backward regions are also the more rigid ones, because, though having the same labour market institutions as more developed regions, they have less competitive product markets. If the central bank does not adjust its target inflation index, backward regions will be affected for a longer time by monetary shocks.

The novelty of this paper is to investigate regional inflation persistence, that is, the nature and causes of differences in inflation persistence across regions at a fine level of territorial dis-aggregation in Italy (NUTS 3 regions $^{1}$ ). Italy is a natural candidate for such an investigation, since the Italian regional divide is a well known problem, with Northern Italy being the most developed part of the country followed by the Centre and then by the South and Islands, also called "Mezzogiorno" (Brunello et al. 2001). Furthermore, the "Mezzogiorno" ghost has been evoked in trying to understand regional disparities within other European countries, notably Germany (Sinn and Westermann, 2001). Therefore, Italy appears to be an ideal laboratory where studying how inflation persistence may interact with regional disparities.

Moreover, from a methodological point of view, with respect to the previous literature: (i) we test if the differences in inflation persistence across regions are statistically significant, by means of a poolability test; (ii) we test the impact of possible structural breaks on the degree of persistence in inflation, employing a non parametric

\footnotetext{
${ }^{1}$ NUTS is the French acronym for Nomenclature of Territorial Units for Statistics used by Eurostat. In this nomenclature NUTS1 refers to European Community Regions and NUTS2 to Basic Administrative Units, with NUTS3 reflecting smaller spatial units most similar to counties in the US.
} 
test on the estimated kernel density functions pre-break and post-break; (iii) we investigate the possible causes of these differences in inflation persistence across Italian regions using both non-parametric and parametric estimation methods.

The rest of this paper is structured as follows. In the next section, we will deal with our estimates of inflation persistence. Then, we will illustrate its link with the local degree of competitiveness of the retail sector.

\section{Estimating Persistence at the Regional Level}

The Italian Statistical Office (ISTAT) has a long tradition in collecting data about prices in the main cities of NUTS3 regions. In this contribution we consider the data for the Consumer Price Index (CPI) from 1996Q1 to 2006Q3 at quarterly frequency for 70 out of 103 Italian provinces. The period under scrutiny is very similar to that studied by Lünnemann and Mathä (2004). We can distinguish 3 groups of provinces according to the number of observations. Five provinces have 36 observations $^{2}$, two provinces 40 observations $^{3}$ and all the rest 43 observations ${ }^{4}$. All the time series are continuous.

For each provincial index we estimate a univariate autoregressive process with a constant, as illustrated by the following equation

$$
\pi_{i t}=\alpha_{i}+\sum_{k_{i}=1}^{K_{i}} \beta_{i k_{i}} \pi_{i t-k_{i}}+\sum_{j=1}^{3} \gamma_{i j} m_{i j t}+u_{i t}
$$

where $\pi_{i t}$ is the inflation rate in province $i$ at time $t, m_{i j t}$ is a quarterly dummy accounting for the possible effects of seasonality, $u_{i t}$ is a stochastic error, $\alpha_{i}, \beta_{i k i}$ and $\gamma_{i j}$ are the parameters to be estimated, $K_{i}$ is the maximum lag length chosen for province $i$.

We choose the optimal lag length resorting to the Schwartz criterion, starting from a maximum lag length of 4 . The selected optimal lag length was equal to one for 27 provinces, to 2 for 15 provinces, to 3 for 18 provinces and to 4 for 10 provinces.

Our indicator of inflation persistence is the sum of the autoregressive coefficients:

\footnotetext{
${ }^{2}$ Vercelli, Livorno, Latina, Teramo and Sassari.

3 Sondrio and Macerata.

4 Torino, Novara, Cuneo, Asti, Alessandria, Aosta, Savona, Genova, Spezia, Varese, Como, Milano, Pavia, Cremona, Mantova, Bolzano, Trento, Verona, Belluno, Treviso, Venezia, Padova, Rovigo, Udine, Trieste, Piacenza, Parma, Reggio Emilia, Modena, Bologna, Ferrara, Ravenna, Forlì, Pesaro, Ancona, Ascoli Piceno, Lucca, Pistoia, Firenze, Pisa, Arezzo, Siena, Grosseto, Perugia, Terni, Viterbo, Roma, Napoli, L’Aquila, Pescara, Chieti, Campobasso, Foggia, Bari, Brindisi, Potenza, Cosenza, Trapani, Palermo, Catania, Siracusa, Cagliari, Pordenone.
} 


$$
\rho_{i}=\sum_{k_{i}=1}^{K_{i}} \beta_{i k_{i}}
$$

A number of measures of persistence have been offered in the literature and they usually return comparable results. It is worth stressing that one of the advantages of the sum of the autoregressive coefficients compared to other measures of persistence is that its confidence interval is very easy to compute (Andrews and Chen, 1994). Thus, a poolability test is rather straightforward and, as in Lünnemann and Mathä (2004), we stick to this simple measure.

After estimating the model for the whole sample, we test - by means of Wald tests robust to heteroskedasticity - the restrictions of $\rho$ being equal to zero or one, and for the presence of a structural break in the intercept and in $\rho$. For the last two tests, we take as possible reference times the EMU kick-off (1999Q1) and the introduction of Euro banknotes and coins (2002Q1). These possible breakpoints were chosen because a change in the monetary regime might affect the pricing behaviour of economic agents ${ }^{5}$. We also test, first, for a structural break in the variance by means of an F test, second, for the presence of serial correlation resorting to Durbin's $m$ test ${ }^{6}$, which is recommended for autoregressive models (Dezhbakhsh, 1990), and third for omitted variables by means of a RESET test. Finally, we perform a poolability test ${ }^{7}$ to control whether the estimates of $\rho$ obtained for each province are statistically different. Indeed, different lag lengths in different provinces are a rather strong sign of geographic heterogeneity, however this does not per se imply that $\rho$ is different across provinces.

In general, we find a rather low level of persistence: across different provinces $\rho$ has an average of 0.25 and a standard deviation of $0.24^{8}$. Table 1 shows the results of

\footnotetext{
5 “[T]he launch of European Monetary Union and the establishment of a clearly defined nominal anchor [was] the defining event that changed the very nature of the inflationary process in the Euro area. This institutional break has eradicated the "intrinsic" component of the inflation formation mechanism, namely the extent to which economic agents-in resetting prices or negotiating wages-look at the past history of inflation, rather than into the eyes of the central bank" (Trichet, 2007, quoted in Benati, 2008).

${ }^{6}$ We always test for an order of serial correlation equal to the number of lags detected by the Schwartz criterion for the autoregressive model of inflation. So if, for instance, the Schwartz criterion points to an AR(3) model for inflation, we will test for third order serial correlation in the residuals.

${ }^{7}$ A Wald test robust to heteroskedasticity with null hypothesis that all the provinces have the same $\rho$.

${ }^{8}$ This low level of persistence is confirmed by unit root testing after Im, Pesaran and Shin (2003) and Bornhorst and Baum (2001). We divide the provinces here considered according to their number of observations and we perform one test for each group of provinces. The number of lags in the test is chosen in the following way. First a panel AR(1) model with fixed effects is estimated, then its residuals
} 
the specification tests. It is evident that structural breaks do not appear to play a major role in our sample. These results are similar to those of Lünnemann and Mathä (2004) and consistent with those of Angeloni et al. (2006), who find a structural break in the inflation process in EMU member states in the mid-90s and a low, stable degree of inflation persistence thereafter. Given the low level of persistence, resorting to more sophisticated methods to avoid bias or unreliable inference does not seem necessary (Andrews and Chen, 1994 and Hansen, 1999). Also serial correlation in the residuals does not affect our results and the autoregressive model of inflation does not appear to be plagued by the omission of relevant variables ${ }^{9}$.

To further explore the impact of possible structural breaks on $\rho$, we estimate its kernel density function for the complete, pre-break and post-break estimates. Figure 1 shows that structural breaks do not appear to have sizeable effects on the regional distribution of inflation persistence in our data, with the exception of the 2002 case where the number of provinces with a negative $\rho$ increases somewhat. However, a Li test for equality between the regional distribution of $\rho$, before and after the structural break, could never reject the null returning a p-value of respectively 0.21 and 0.82 for the 1999 and the 2002 cases.

Finally, the poolability test is strongly rejected. Regional disparities in inflation persistence are quite remarkable. The average of $\rho$ is rather similar in the North East and in the North West of Italy, where it is respectively equal to 0.22 and 0.21 . Whereas in both the Centre and the South and Islands it is about $40 \%$ higher $^{10}$. Therefore, inflation persistence appears to be greater in the lagging part of the country ${ }^{11}$.

are computed. Finally, an AR model is estimated on the residuals and the number of lags is chosen thanks to a Schwartz criterion. The same number of lags is then used in the Im, Pesaran and Shin (2003) tests. Following Baltagi (2003) we do not insert any time trend in the model. The presence of unit roots was rejected at a $1 \%$ level for the provinces with 40 or more observations and at a $5 \%$ level for the provinces with 36 observations.

9 Therefore the results here obtained are robust to the possible misspecification problems highlighted by Vaona (2007) with reference to simple autoregressive models applied to long aggregate inflation time series for 19 countries.

10 The few structural breaks detected were concentrated among Northern provinces more than Southern ones. For the 2002 tests, we found a structural break in the intercept in the provinces of Asti (North), Como (North), Livorno (Centre), Lucca (Centre), Reggio Emilia (North), Rovigo (North), Trapani (South), Varese (North). A structural break in $\rho$ was found in the provinces of Alessandria (North), Ancona (Centre), Bari (South), Bologna (North), Bolzano (North), Como (North), Firenze (Centre), Latina (Centre), Lucca (Centre), Padova (North), Palermo (South), Pesaro (Centre), Pisa (Centre), Rovigo (North), Sassari (South), Siracusa (South), La Spezia (North). Similar results were found when testing for structural breaks in 1999. It is therefore possible to exclude that the result of greater inflation persistence 
Remarkably, once estimating an autoregressive model on national inflation data we obtain an estimate of $\rho$ equal to 0.26 , significantly different from both 0 and 1 . No structural break, no serial correlation and no omitted variable is detected. The Schwartz criterion chooses an AR(1) model as the most suitable specification. The estimate of $\rho$ is very close to the cross-section mean of provincial estimates, entailing that, contrary to the findings of Altissimo et al. (2007) for sectoral data, aggregate inflation series might not inherit the properties of the more persistent disaggregate regional inflation series. As a consequence, in order to avoid welfare losses Central Banks should compute their target inflation index giving more weight to more persistent regions as suggested by Benigno (2004).

\section{Regional Inflation Persistence and the Retail Sector}

In order to shed further light on the possible sources of the geographical pattern above, we investigate the connection between regional inflation persistence and the structure of the retail sector. Recent empirical contributions have compared the persistence properties of consumer and producer price indexes in Italy (Sabbatini et al., 2004). These works show that the rate of change of the consumer price index displays more persistence than the producer price index, pointing to the degree of competitiveness of the retail sector as one of the possible sources of inflation persistence. In the present paper, we show that more persistent regions tend to have a less competitive retail sector.

The retail sector is often regulated at the local level and Italy makes no exception (Boylaud and Nicoletti, 2001). Furthermore, recent reforms, though originally aiming at liberalizing the sector, actually increased the regulatory power of local authorities,

\footnotetext{
in the Centre and South is spurious, due to more structural breaks there, as structural breaks appeared more often in the North for the intercept, while for $\rho$ they were concentrated in the North and in the Centre to a similar extent.

${ }^{11}$ Poolability has been at the centre of a number of different recent econometric contributions. Baltagi et al. (2003) and Baltagi et al. (2004) recommended adopting pooled estimators because they provide better forecasts and more plausible estimates. In our context we are not concerned with forecasting. Regarding the plausibility of estimates, we can distinguish poolability across space and across time. Inspecting Figure 1 it is possible to see that heterogeneity across space and homogeneity across time provide plausible estimates. Once allowing for structural breaks and therefore not pooling across time, we cannot rule out that inflation has an explosive behaviour in some provinces, which is contrary to the evidence on convergence of regional inflation rate in Italy provided by Vaona (2007) and by Busetti et al. (2006).
} 
which often used it to inhibit competition, limiting the entry of large stores (Schivardi and Viviano, 2006).

The entry of large stores would generally be beneficial for competition, but only to the extent that they do not acquire local monopolistic power. On the other hand, if the effect of market regulation were to protect small shops, boosting their share in the total number of firms belonging to the sector, local monopoly power would tend to increase. Therefore, the connection between firm size and competitiveness in the retail sector is a rather complex one entailing possible non-linearities.

Regarding the connection between competitiveness and inflation persistence, a lower degree of competitiveness would induce higher inflation persistence through two channels. First, Leith and Mulley (2003) show that firms in a less competitive environment tend to adjust prices less frequently and are less likely to do so in a forward-looking manner. Second, the recent New Keynesian literature suggests that inflation persistence requires the existence of "rule of thumbers" among price setters (Galí and Gertler, 1999, and Altissimo et al., 2006). Intuitively, small shops are good candidates for "rule of thumb" price-setters, because they are unlikely to have the ability to forecast future inflation.

To this regard, Veronese et al. (2004) analyse the price dynamics of items of a specific brand sold in a specific outlet, for a total of 750,000 elementary price quotes in the Italian CPI basket. One finding is that traditional outlets tend to change the price significantly less frequently than large stores.

Following the results of the studies above, we want, therefore, to check in our database if there is a link between inflation persistence and the competitiveness of the retail sector, which we try to capture by means of two indicators. We consider both the large store floor space over resident population (LS) and, after Boylaud and Nicoletti (2001), the share of firms with no more than two employees in the retail sector, the "mom-and-pop stores" $(M P)^{12}$. The former indicator is available for 1999 from Schivardi and Viviano (2007), while the latter one is available from the 2001 census.

\footnotetext{
${ }^{12}$ Following Cirinko and Fazzari (2000) it would be possible to argue that inflation persistence causes more than it is caused by the degree of competitiveness of the retail sector. Suppose that after a shock inflation takes more time to go back to its steady state value in a region with respect to an other, this will induce economic agents in the first region to spend more time shopping in search for better deals, decreasing monopoly rents in the retail sector. However, to the extent that - building on Schivardi and Viviano (2006) and on Boylaud and Nicoletti (2001) - regional variation in LS and MP can be attributed to local product market regulations, we can consider these variables as exogenous.
} 
The South of Italy has a higher incidence of small shops than the North, where large stores gained ground in recent decades (Argiolas and Ventura, 2002).

However, inflation persistence might be driven by other factors than the degree of competitiveness of the local retail sector. In particular we would like to test two hypotheses. The first one is whether regional disparities in inflation persistence might also originate from local labour market characteristics, even though different regions of a country usually share the same labour market institutions. The second hypothesis is whether the industrial mix of a region has an impact on inflation persistence.

In order to test the first hypothesis we add the average of the local unemployment rate between 1998 and 2005 (AU9805) as one further explanatory variable. Suppose that wage rigidity, induced by labour market institutions, produces a higher unemployment rate. If wage rigidity is also the source of a more pronounced inflation persistence, a higher unemployment rate will be connected to a greater inflation persistence.

In order to test the second hypothesis we include in the model the average share of service activities in total local value added between 1996 and 2003 (SS9603). We also insert a set of regional dummies, to account for further factors that we might not directly capture $(D)$. Descriptive statistics for the proposed explanatory variables are showed in Table 2.

We start investigating by a non-parametric estimator a possible non linear relationship between inflation persistence and the large store surface over resident population in 1999. Figure 2 shows that their relationship appears to be negative up to approximately 220 squared meters per 1000 inhabitants and positive thereafter. As a consequence we add to the explanatory variables above the square of large store surface over resident population in 1999. Regarding the share of small firms in the retail sector, non-linearities are far less marked (Fig. 3), therefore we specify a linear model for this variable, not neglecting, however, to test for possible omitted non-linearities in the residuals.

To sum up the estimated model is

$$
\rho_{i}=\delta_{0}+\delta_{1} L S_{i}+\delta_{2} L S_{i}^{2}+\delta_{3} M P_{i}+\delta_{4} A U 9805_{i}+\delta_{5} S S 9603_{i}+\delta_{6} D_{N E}+\delta_{7} D_{N W}+\delta_{8} D_{S}+\varepsilon_{i}
$$

where $\delta_{k}$ for $k=0, \ldots, 8$ are coefficients, $\varepsilon_{i}$ are stochastic errors, $D_{j}$ for $j=\mathrm{NE}, \mathrm{NW}, \mathrm{S}$ are regional dummies for the North East (NE), the North West (NW) and the South (S) of 
Italy. The control group is therefore made by provinces belonging to the Centre of Italy $^{13}$.

Table 3 shows estimation results. The only regressors with a significant coefficient are those concerning the competitive structure of the retail sector. The higher is the share of "mom-and-pop" stores within the retail sector and the higher is inflation persistence. Non-parametric results concerning the ratio of large stores floor over resident population are confirmed. The presence of large stores decreases inflation persistence up to a threshold level, after which they increase it due to their nonlinear effect on competitiveness explained above.

The estimated model supports the view that regional inflation persistence is positively affected by the degree of monopoly power in the retail sector, as suggested by the New Keynesian theoretical literature. On the contrary, the local labour market conditions and the sectoral composition of the regional economy do not affect regional inflation persistence.

Moreover, as showed in Table 4, the residuals of the proposed model are very well behaved. Their normality could not be rejected by a battery of tests, as well as the fact that they have zero mean. A test for spatial correlation could not reject the absence of spatial correlation in the residuals ${ }^{14}$. A RESET test, obtained adding to the right hand side of (3) the square of the fitted values of the model (Davidson and MacKinnon, 1999), could not detect the presence of either omitted variables or of further nonlinearities. This result is also supported by a non-parametric test after Ellison and Ellison (2000) and by further RESET tests obtained by adding to the model in the first instance the squares and the cubes of the fitted values and, then, their cubes and fourth powers, that returned respectively a p-value of 0.31 and 0.39 .

\footnotetext{
${ }^{13}$ It is worth noting that $\rho_{i}$ is an estimated dependent variable, which might induce heteroskedasticity. We follow Lewis and Linzer (2005) and we compute a robust OLS, a WLS and a FGLS estimator. However, as showed by Table 3 and by Table A1 in the Appendix, we obtained very similar results for all three of them. Though in Monte Carlo Simulations Lewis and Linzer (2005) found that the OLS and FGLS estimators can outperform the WLS one, in practice they may well return very similar results as in the present application and in the "Prospective Models" of Table 3 in Lewis and Linzer (2005).

${ }^{14}$ Testing for spatial correlation in the residuals is important because its presence might induce biased standard errors and unreliable statistical inference. We used as weight matrix a contiguity matrix whose elements are equal to one for bordering provinces and zero otherwise.
} 


\section{Conclusions}

In this contribution we assessed the issue if there exist statistically significant differences in inflation persistence at the regional level in a country with sizeable regional disparities like Italy. Our results point to the fact that economically backward regions also have greater inflation persistence, which does not show up in the aggregate inflation rate. With this result in mind, it is not surprising that the unemployment rate increased more in the South than in the North during the deflation of the nineties (Brunello et al., 2001), as more persistence in inflation means a larger sacrifice ratio. In accordance with recent theoretical contributions (Benigno, 2004), our results stress the need for monetary policy to take into consideration dispersion in regional inflation persistence, supplementing traditional inflation indicators, with one that weighs regional inflation time series according to their persistence. Finally, another important result of our analysis is that different levels of regional inflation persistence are associated with different local degrees of competitiveness in the retail sector.

\section{References}

[1] Altissimo, F., Mojon, B. and P. Zaffaroni (2007). Fast Micro and Slow Macro: Can Aggregation Explain the Persistence of Inflation?, ECB Working Paper No. 729, ECB, Frankfurt

[2] Altissimo, F., Ehrmann, M. and F. Smets (2006). Inflation Persistence and Price Setting Behaviour in the Euro area, Occasional Paper 46, ECB, Frankfurt.

[3] Andrews, D. and H. Y. Chen (1994). Approximately Median Unbiased Estimation of Autoregressive Models”, Journal of Business and Economic Statistics, Vol. 12, pp. 187-204.

[4] Anselin, L. (1988). Spatial Econometrics: Methods and Models, Kluwer, Dordrecht.

[5] Angeloni, I., Aucremanne, L. and M. Ciccarelli. (2006). "Price Setting and Inflation Persistence: Did EMU Matter?”, Economic Policy, Vol. 21, pp. 353-387.

[6] Argiolas, B. and F. Ventura (2002). "La liberalizzazione del commercio al dettaglio: una prima verifica [Retail Trade Liberalization: a Preliminary 
Assessment]”, ISAE Rapporto trimestrale, ISAE, http://www.isae.it/cap5_estratto_rapp_trim_04_02.pdf.

[7] Baltagi, Badi H. (2003). Econometric Analysis of Panel Data, Wiley, Chichester.

[8] Baltagi, Badi H., Bresson, Georges, Griffin, James M. and Alain Pirotte (2003), "Homogeneous, heterogeneous or shrinkage estimators? Some empirical evidence from French regional gasoline consumption, Empirical Economics, Vol. 28, pp. 795-811.

[9] Baltagi, Badi H., Bresson, Georges and Alain Pirotte (2004), “Tobin q: Forecast performance for hierarchical Bayes, shrinkage, heterogeneous and homogeneous panel data estimators”, Empirical Economics, Vol. 29, pp. 107113.

[10] Beck, G. W., and A. A. Weber (2005a). Price Stability, Inflation Convergence and Diversity in EMU: Does One Size Fit All?, CFS Working Paper No. 2005/30.

[11] Beck, G. W., and A. A. Weber (2005b). Inflation Dispersion and Convergence in Monetary and Economic Unions: Lessons for the ECB, CFS Working Paper No. 2005/31, forthcoming in the International Journal of Central Banking.

[12] Beck, G. W., Hubrich, K., and M. Marcellino (2006), Regional Inflation Dynamics Within and Across Euro Area Countries and a Comparison with the US, ECB Working Paper No. 681, ECB, Frankfurt.

[13] Benati, Luca (2008), "Investigating inflation persistence across monetary regimes”, ECB Working Paper No. 851, ECB, Frankfurt.

[14] Benigno, P. (2004). “Optimal Monetary Policy in a Currency Area”, Journal of International Economics 63, pp. 293-320.

[15] Benigno, P. and D. López Salido (2006). "Inflation persistence and optimal monetary policy in the euro area”, Journal of Money, Credit and Banking, Vol. 38, pp. 587-614.

[16] Bornhorst, Fabian and Christopher Baum (2001). IPSHIN: Stata Module to perform Im-Pesaran-Shin panel unit root test, Statistical Software 
Components S419704, Boston College, Department of Economics, revised 11 Jun 2007.

[17] Boylaud, O. and G. Nicoletti (2001). Regulatory Reform in Retail Distribution, OECD Economic Studies 32, OECD, Paris.

[18] Busetti, F., Fabiani, S., and A. Harvey, (2006), “Convergence of Prices and Rates of Inflation”, Oxford Bulletin of Economics and Statistics, Vol.68, pp. 863-877.

[19] Brunello, G., C. Lupi and P. Ordine (2001). "Widening Differences in Italian Regional Unemployment”, Labour Economics, Vol. 8, pp. 103-129.

[20] Campbell, L. and J. Malley (2003). “A Sectoral Analysis of Price-Setting Behavior in US Manufacturing Industries”, The Review of Economics and Statistics, 89, pp. 335-342.

[21] Cecchetti, S. G., Mark, N. C., and Sonora, R. (2002). "Price level convergence among united states cities: Lessons for the European Central Bank”, International Economic Review, Vol. 43, pp.1081-1099.

[22] Cecchetti, S.G., and G. Debelle (2006), “Inflation Persistence”, Economic Policy, Vol. 21, pp. 311-352.

[23] Cirinko, Robert S., Fazzari Steven M. (2000), "Market Power and Inflation”, The Review of Economics and Statistics, Vol. 82, pp. 509-513.

[24] Davidson, R. and J. G. MacKinnon (2004). Econometric Theory and Methods, Oxford University Press, Oxford, UK.

[25] Dezhbakhsh, H., (1990), “The Inappropriate Use of Serial Correlation Tests in Dynamic Linear Models”, The Review of Economics and Statistics, 72, pp. 126-132.

[26] Dhyne, E., Álvarez, L.J., Le Bihan, H., Veronese, G., Dias, D., Hoffmann, J., Jonker, N., Lünnemann, P., Rumler, F., and J. Vilmunen, (2005), Price Setting in the Euro Area, Some Stylized Facts from Individual Consumer Price Data, ECB Working Paper No. 524, ECB, Frankfurt.

[27] Eisenhauer, J. G. (2003), "Regression through the origin”, Teaching Statistics, 25: $76-80$.

[28] Ellison, G., and S., Ellison, (2000), “A simple framework for nonparametric specification testing”, Journal of Econometrics, 96: 1-23. 
[29] Galí, J., and M. Gertler (1999), "Inflation Dynamics: A Structural Econometric Analysis”, Journal of Monetary Economics, Vol. 44, 195-222.

[30] Hansen, B. E., (1999), “The Grid Bootstrap and the Autoregressive Model”, The Review of Economics and Statistics, Vol. 81, 594-607.

[31] Im, K., H. Pesaran and Y. Shin (2003), "Testing for Unit Roots in Heterogeneous Panels”, Journal of Econometrics, 115, 53-74.

[32] Lewis, Jeffrey B. and Drew A. Linzer, (2005), “Estimating Regression Models in Which the Dependent Variable Is Based on Estimates”, Political Analysis, 13, 345-364.

[33] Lünnemann, P. and T. Mathä (2004), How Persistent is Disaggregate Inflation? An Analysis across EU Countries and HICP Subindices, ECB Working Paper No. 415, ECB, Frankfurt.

[34] Miles, D. and J. Mora (2003), "On the Performance of Nonparametric Specification Tests in Regression Models”, Computational Statistics and Data Analysis, Vol. 42, pp. 477 - 490.

[35] Sabbatini, R., Fabiani, S., Gattulli, A. and G. Veronese (2004). Producer Price Behaviour in Italy: Evidence from Micro PPI Data, Banca d'Italia.

[36] Schivardi, F. and E. Viviano (2006). Entry Barriers in Italian Retail Trade, Temi di Discussione 616, Banca d'Italia.

[37] Sinn, H. W. and F. Westermann (2001). Two Mezzogiornos, NBER Working Paper 8125.

[38] Trichet, Jean-Claude (2007). “The Euro Area and its Monetary Policy,” Address by Jean-Claude Trichet, President of the ECB at the conference "The ECB and its Watchers IX”, Frankfurt am Main, 7 September 2007.

[39] Vaona, A. (2007), Inflation Persistence, Structural Breaks and Omitted Variables: a Critical View, Quaderni della facoltà di Scienze economiche dell'Università di Lugano, 0802, Biblioteca universitaria di Lugano.

[40] Vaona, A. (2007a) Merging the purchasing power parity and the Phillips curve literatures: regional panel data evidence from Italy. International Regional Science Review, 30: 152-172. 
[41] Veronese, G., Fabiani S., Gattulli, A. and R. Sabbatini (2004). Consumer

Price Behaviour in Italy: Evidence from Micro CPI Data, ECB Working Paper No. 449, ECB, Frankfurt.

Table 1 - Model specification tests - based on regional inflation time series at quarterly frequency (Total number of series: 70)

\begin{tabular}{|c|c|c|c|}
\hline $\begin{array}{l}\text { Wald test on the sum of the } \\
\text { autoregressive coefficients to } \\
\text { be equal to zero }{ }^{\dagger}\end{array}$ & 0.41 & $\begin{array}{l}\text { Wald test on a structural } \\
\text { change in the intercept } \\
(2002 Q 1)^{\ddagger}\end{array}$ & 0.89 \\
\hline $\begin{array}{l}\text { Wald test on the sum of the } \\
\text { autoregressive coefficients to } \\
\text { be equal to one }{ }^{\dagger}\end{array}$ & 0.03 & $\begin{array}{l}\text { One sided F-test on a } \\
\text { structural change in the } \\
\text { standard deviation of } \\
\text { inflation (1999Q1) }\end{array}$ & 0.96 \\
\hline $\begin{array}{l}\text { Wald test on a structural } \\
\text { change in sum of the } \\
\text { autoregressive coefficients } \\
(1999 Q 1)^{\ddagger ॰}\end{array}$ & 0.87 & $\begin{array}{l}\text { One sided F-test on a } \\
\text { structural change in the } \\
\text { standard deviation of } \\
\text { inflation }(2002 Q 1)^{\ddagger ॰}\end{array}$ & 0.91 \\
\hline $\begin{array}{l}\text { Wald test on a structural } \\
\text { change in the sum of the } \\
\text { autoregressive coefficients } \\
(2002 Q 1)^{\ddagger 。}\end{array}$ & 0.76 & $\begin{array}{l}\text { Wald test of poolability of } \\
\text { all the provinces } \\
\text { (restricted sample) - p- } \\
\text { value }^{*}\end{array}$ & 0.00 \\
\hline \multirow[t]{2}{*}{$\begin{array}{l}\text { Wald test on a structural } \\
\text { change in the intercept } \\
(1999 Q 1)^{\ddagger}\end{array}$} & 0.90 & $\begin{array}{l}\text { Durbin's } \boldsymbol{m} \text { test for serial } \\
\text { correlation }^{\ddagger \ddagger}\end{array}$ & 1 \\
\hline & & $\begin{array}{l}\text { RESET test for model } \\
\text { misspecification }\end{array}$ & 0.99 \\
\hline
\end{tabular}

\footnotetext{
$\circ:$ tests based on heteroskedasticity consistent standard errors.

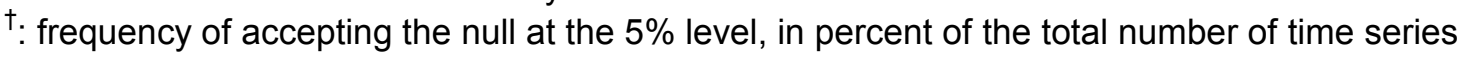

f. frequency of accepting the null of no break at the $5 \%$ level, in percent of the total number of time series analysed.

*: the test is distributed as a chi squared with 69 degrees of freedom. The null is that all the provinces can be pooled, namely that each province has the sum of autoregressive coefficients equal to that of Vercelli in the North-West of Italy (Piemonte region).

$\ddagger \ddagger$ : frequency of accepting the null at the $5 \%$ level of no serial correlation in the residuals, in percent of the total number of time series analysed.

$\ddagger \neq$ : frequency of accepting the null at the $5 \%$ level of no model misspecification, in percent of the total number of series analysed. The test was obtained by adding to the model the squares and the cubes of the regressors and testing for the significance of their coefficients.
} 
Figure 1 - Regional Distribution of Inflation Persistence - General Consumer Price Index

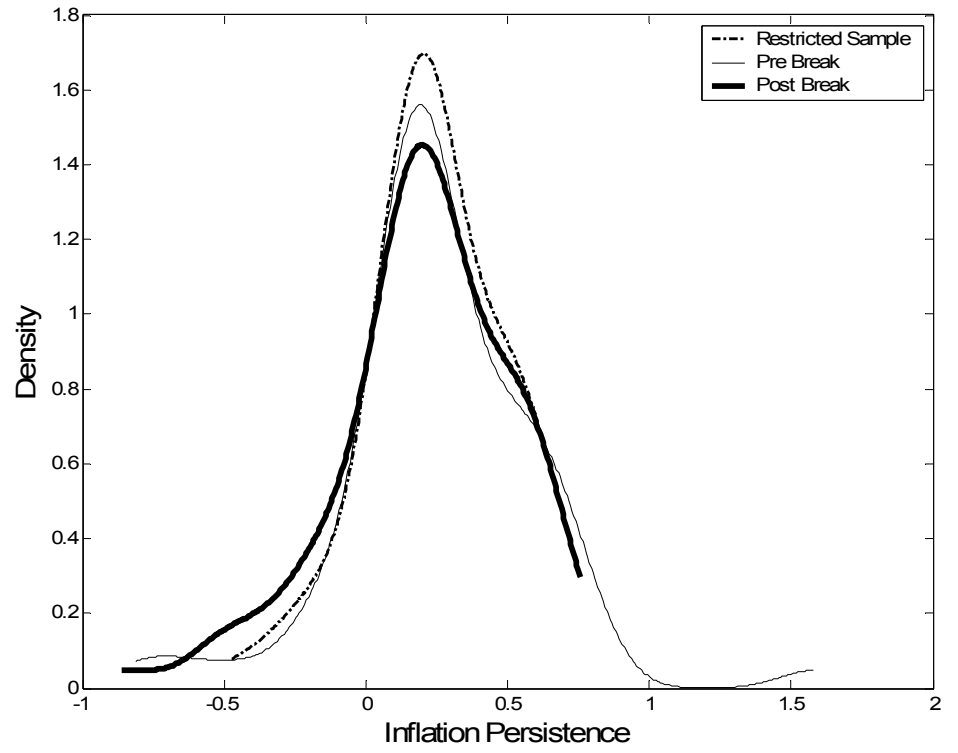

Break in 1999Q1

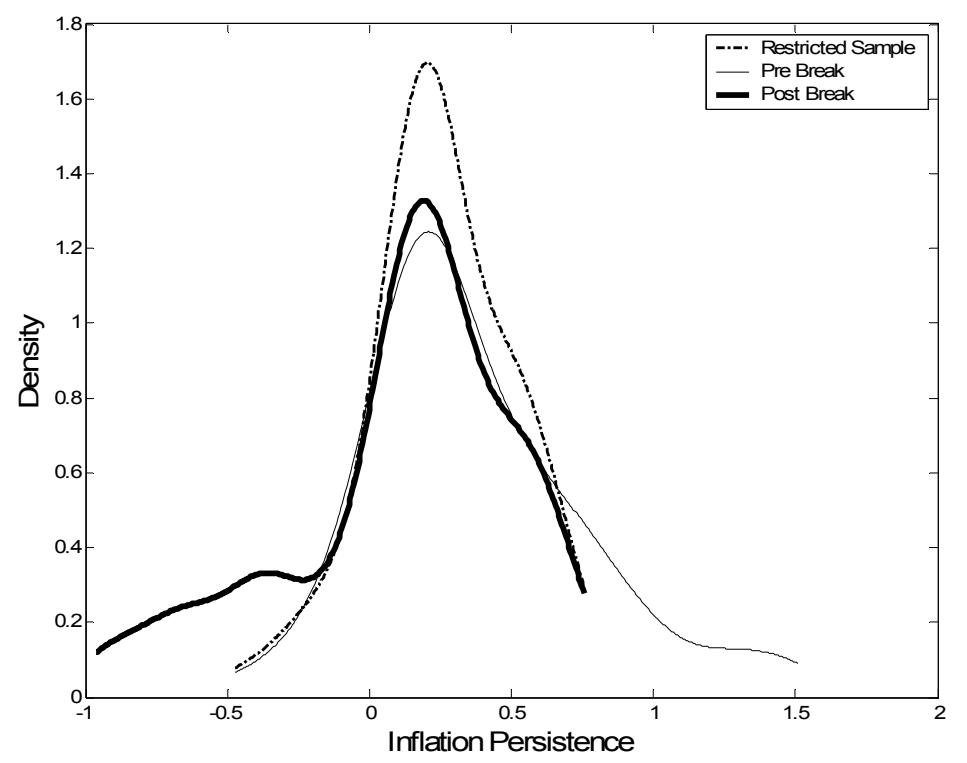

Break in 2002Q1

Note: kernel density estimators with Silverman's optimal smoothing bandwidth. The inflation persistence measure is the sum of the coefficients of autoregressive processes estimated for the Italian provinces included in the sample. The number of lags was selected thanks to a Schwartz criterion. For the reasons underlying the choice of this persistence measure see the body of the paper. 
Figure 2 - Nonparametric estimator of the relationship between regional inflation persistence and total large store surface over resident population in 1999.

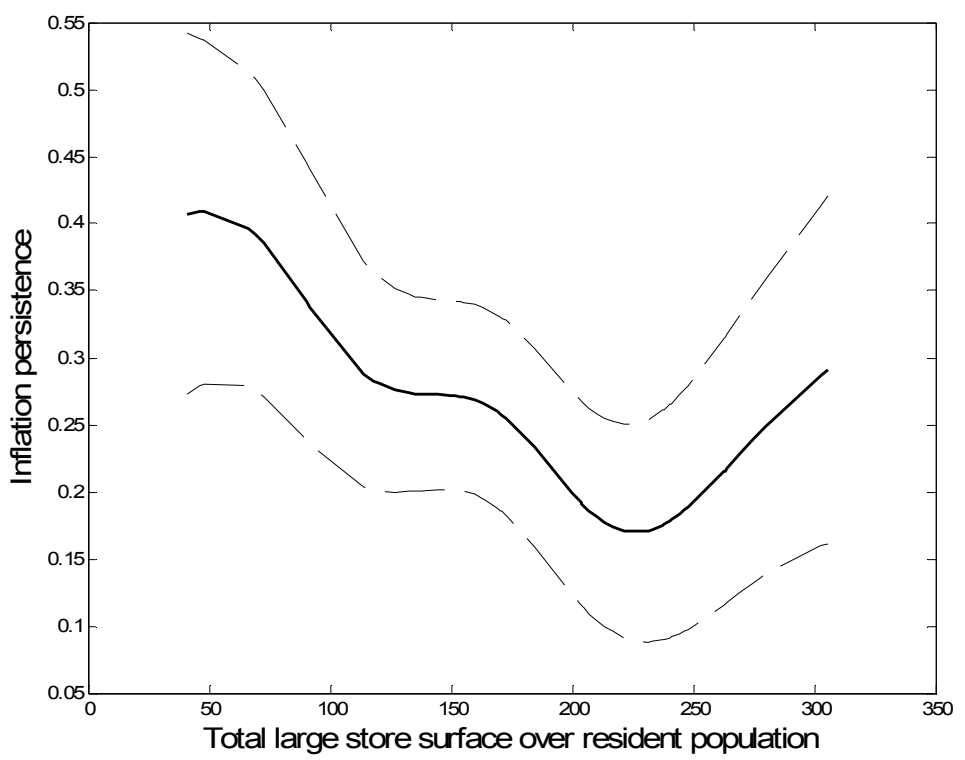

Note: for this picture we resorted to a Gaussian kernel estimator with Silverman's optimal smoothing bandwidth.

Figure 3 - Nonparametric estimator of the relationship between regional inflation persistence and the share of stores with less than 3 employees in 2001.

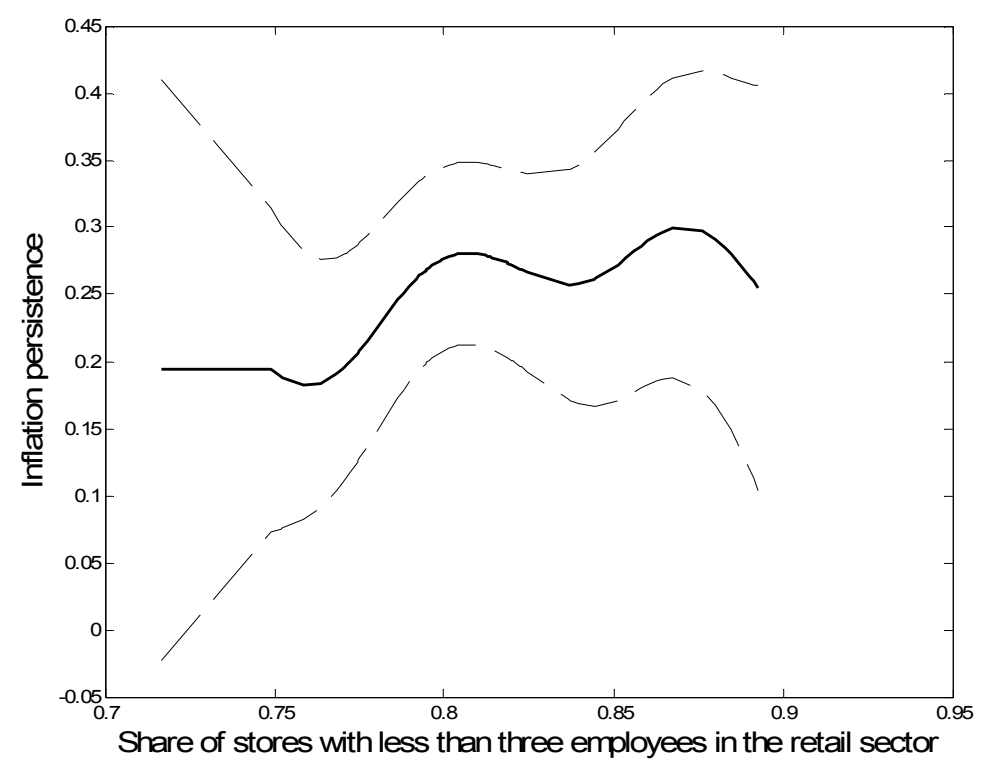

Note: for this picture we resorted to a Gaussian kernel estimator with Silverman's optimal smoothing bandwidth. 
Table 2 - Descriptive statistics of the regressors

\begin{tabular}{c|cccc}
\hline \hline & Mean & Std. Dev. & Min. & Max. \\
\hline \hline $\begin{array}{c}\text { Total large store surface in 1999 } \\
\text { (squared meters per thousands of } \\
\text { inhabitants) }\end{array}$ & 182.13 & 65.13 & 41.13 & 305.65 \\
$\begin{array}{c}\text { Share of retail stores with less than 3 } \\
\text { employees in 2001 }\end{array}$ & 0.81 & 0.05 & 0.65 & 0.89 \\
$\begin{array}{c}\text { Average unemployment rate between } \\
\mathbf{1 9 9 8} \text { and 2005 }\end{array}$ & 8.18 & 5.58 & 2.36 & 25.04 \\
$\begin{array}{c}\text { Share of service activities in total } \\
\text { local value added between 1996 and } \\
\mathbf{2 0 0 3}\end{array}$ & 0.71 & 0.08 & & \\
\hline
\end{tabular}

Table 3 - The determinants of regional inflation persistence

Dependent variable: inflation persistence. Estimation method: Ordinary Least Squares wit Robust Standard Errors. Observations: 70.

\begin{tabular}{l|rr}
\hline \hline & Coefficients & t-statistics \\
\hline Total large store surface over resident population in 1999 & $-0.005^{*}$ & -2.45 \\
(Total large store surface over resident population in 1999) $^{2}$ & $0.001^{*}$ & 2.37 \\
Share of retail stores with less than 3 employees in 2001 & $0.905^{*}$ & 2.39 \\
Average unemployment rate between 1998 and 2005 & -0.009 & -0.78 \\
Share of service activities in total local value added between 1996 and 2003 & 0.202 & 0.57 \\
North East Italy $^{\dagger}$ & -0.070 & -1.05 \\
North West Italy $^{\dagger}$ & -0.102 & -1.18 \\
South and Islands $^{\dagger}$ & -0.039 & -0.23 \\
\hline
\end{tabular}

Following Eisenhauer (2003), the constant was dropped because it was not significantly different from zero at a $5 \%$ level.

${ }^{\dagger}$ : dummy variables. The control group is constituted by provinces belonging to Central Italy.

*: significant at a $5 \%$ level. 
Table 4 - Tests on the residuals of the model of the determinants of regional inflation persistence (Table 2)

\begin{tabular}{lc}
\hline Normality tests & \\
\hline Shapiro - Francia (p-value) $^{\circ}$ & 0.42 \\
Shapiro - Wilk (p-value) $^{\circ}$ & 0.54 \\
Skeweness - Kurtosis (p-value) $^{\circ}$ & 0.59 \\
\hline RESET test for omitted variables (p-value) $^{\dagger}$ & 0.58 \\
Test for zero mean residuals (p-value) $^{\dagger \dagger}$ & 0.97 \\
Test for spatial correlation $^{\dagger \dagger o}$ & 0.84 \\
Ellison and Ellison (p-value) $^{\dagger \dagger o 0}$ & 0.81 \\
Observations $^{\text {Obs }}$ & 70 \\
\hline \hline
\end{tabular}

o: the null is that residuals have a normal distribution.

$t$ : the null is absence of omitted variables.

$\dagger+$ : the null is that residuals have a zero mean.

††o: the test for spatial correlation is the Moran's I statistic which is distributed as $N(0,1)$ and whose $5 \%$ critical value is 1.96 . The null is absence of spatial correlation. For an introduction to this test see Anselin (1988).

††oo: the null is that the model fits the data well in terms of functional specification and omitted variables. We used a quartic kernel function as in Miles and Mora (2003) and Silverman's optimal smoothing bandwidth as window width. The test has an asymptotic standard normal distribution. 
QUADERNI DELLA FACOLTÀ

I quaderni sono richiedibili (nell'edizione a stampa) alla Biblioteca universitaria di Lugano via G. Buffi 13 CH 6900 Lugano

e-mail: biblioteca@lu.unisi.ch

The working papers (printed version) may be obtained by contacting the Biblioteca universitaria di Lugano

via G. Buffi 13 CH 6900 Lugano

e-mail: biblioteca@lu.unisi.ch

Quaderno n. 98-01

P. Balestra, Efficient (and parsimonious) estimation of structural dynamic error component models

Quaderno n. 99-01

M. Filippini, Cost and scale efficiency in the nursing home sector : evidence from Switzerland

Quaderno n. 99-02

L. Bernardi, I sistemi tributari di oggi : da dove vengono e dove vanno

Quaderno n. 99-03

L.L. Pasinetti, Economic theory and technical progress

Quaderno n. 99-04

G. Barone-Adesi, K. Giannopoulos, L. Vosper, VaR without correlations for portfolios of derivative securities

Quaderno n. 99-05

G. Barone-Adesi, Y. Kim, Incomplete information and the closed-end fund discount

Quaderno n. 99-06

G. Barone-Adesi, W. Allegretto, E. Dinenis, G. Sorwar, Valuation of derivatives based on CKLS interest rate models

Quaderno n. 99-07

M. Filippini, R. Maggi, J. Mägerle, Skalenerträge und optimale Betriebsgrösse bei den schweizerische Privatbahnen

Quaderno n. 99-08

E. Ronchetti, F. Trojani, Robust inference with GMM estimators

Quaderno n. 99-09

G.P. Torricelli, I cambiamenti strutturali dello sviluppo urbano e regionale in Svizzera e nel Ticino sulla base dei dati dei censimenti federali delle aziende 1985, 1991 e 1995 
Quaderno n. 00-01

E. Barone, G. Barone-Adesi, R. Masera, Requisiti patrimoniali, adeguatezza del capitale e gestione del rischio

Quaderno n. 00-02

G. Barone-Adesi, Does volatility pay?

Quaderno n. 00-03

G. Barone-Adesi, Y. Kim, Incomplete information and the closed-end fund discount

Quaderno n. 00-04

R. Ineichen, Dadi, astragali e gli inizi del calcolo delle probabilità

Quaderno n. 00-05

W. Allegretto, G. Barone-Adesi, E. Dinenis, Y. Lin, G. Sorwar, A new approach to check the free boundary of single factor interest rate put option

Quaderno n. 00-06

G.D.Marangoni, The Leontief Model and Economic Theory

Quaderno n. 00-07

B. Antonioli, R, Fazioli, M. Filippini, Il servizio di igiene urbana italiano tra concorrenza e monopolio

Quaderno n. 00-08

L. Crivelli, M. Filippini, D. Lunati. Dimensione ottima degli ospedali in uno Stato federale

Quaderno n. 00-09

L. Buchli, M. Filippini, Estimating the benefits of low flow alleviation in rivers: the case of the Ticino River

Quaderno n. 00-10

L. Bernardi, Fiscalità pubblica centralizzata e federale: aspetti generali e il caso italiano attuale

Quaderno n. 00-11

M. Alderighi, R. Maggi, Adoption and use of new information technology

Quaderno n. 00-12

F. Rossera, The use of log-linear models in transport economics: the problem of commuters' choice of mode

Quaderno n. 01-01

M. Filippini, P. Prioni, The influence of ownership on the cost of bus service provision in Switzerland. An empirical illustration

Quaderno n. 01-02

B. Antonioli, M. Filippini, Optimal size in the waste collection sector

Quaderno n. 01-03

B. Schmitt, La double charge du service de la dette extérieure 
Quaderno n. 01-04

L. Crivelli, M. Filippini, D. Lunati, Regulation, ownership and efficiency in the Swiss nursing home industry

Quaderno n. 01-05

S. Banfi, L. Buchli, M. Filippini, Il valore ricreativo del fiume Ticino per i pescatori

Quaderno n. 01-06

L. Crivelli, M. Filippini, D. Lunati, Effizienz der Pflegeheime in der Schweiz

Quaderno n. 02-01

B. Antonioli, M. Filippini, The use of a variable cost function in the regulation of the Italian water industry

Quaderno n. 02-02

B. Antonioli, S. Banfi, M. Filippini, La deregolamentazione del mercato elettrico svizzero e implicazioni a breve termine per l'industria idroelettrica

Quaderno n. 02-03

M. Filippini, J. Wild, M. Kuenzle, Using stochastic frontier analysis for the access price regulation of electricity networks

Quaderno n. 02-04

G. Cassese, On the structure of finitely additive martingales

Quaderno n. 03-01

M. Filippini, M. Kuenzle, Analisi dell'efficienza di costo delle compagnie di bus italiane e svizzere

Quaderno n. 03-02

C. Cambini, M. Filippini, Competitive tendering and optimal size in the regional bus transportation industry

Quaderno n. 03-03

L. Crivelli, M. Filippini, Federalismo e sistema sanitario svizzero

Quaderno n. 03-04

L. Crivelli, M. Filippini, I. Mosca, Federalismo e spesa sanitaria regionale : analisi empirica per i Cantoni svizzeri

Quaderno n. 03-05

M. Farsi, M. Filippini, Regulation and measuring cost efficiency with panel data models : application to electricity distribution utilities

Quaderno n. 03-06

M. Farsi, M. Filippini, An empirical analysis of cost efficiency in non-profit and public nursing homes

Quaderno n. 03-07

F. Rossera, La distribuzione dei redditi e la loro imposizione fiscale : analisi dei dati fiscali svizzeri 
Quaderno n. 03-08

L. Crivelli, G. Domenighetti, M. Filippini, Federalism versus social citizenship : investigating the preference for equity in health care

Quaderno n. 03-09

M. Farsi, Changes in hospital quality after conversion in ownership status

Quaderno n. 03-10

G. Cozzi, O. Tarola, Mergers, innovations, and inequality

Quaderno n. 03-11

M. Farsi, M. Filippini, M. Kuenzle, Unobserved heterogeneity in stochastic cost frontier models : a comparative analysis

Quaderno n. 04-01

G. Cassese, An extension of conditional expectation to finitely additive measures

Quaderno n. 04-02

S. Demichelis, O. Tarola, The plant size problem and monopoly pricing

Quaderno n. 04-03

F. Rossera, Struttura dei salari 2000 : valutazioni in base all'inchiesta dell'Ufficio federale di statistica in Ticino

Quaderno n. 04-04

M. Filippini, M. Zola, Economies of scale and cost efficiency in the postal services : empirical evidence from Switzerland

Quaderno n. 04-05

F. Degeorge, F. Derrien, K.L. Womack, Quid pro quo in IPOs : why book-building is dominating auctions

Quaderno n. 04-06

M. Farsi, M. Filippini, W. Greene, Efficiency measurement in network industries : application to the Swiss railway companies

Quaderno n. 04-07

L. Crivelli, M. Filippini, I. Mosca, Federalism and regional health care expenditures : an empirical analysis for the Swiss cantons

Quaderno n. 04-08

S. Alberton, O. Gonzalez, Monitoring a trans-border labour market in view of liberalization: the case of Ticino

Quaderno n. 04-09

M. Filippini, G. Masiero, K. Moschetti, Regional differences in outpatient antibiotic consumption in Switzerland

Quaderno n. 04-10

A.S. Bergantino, S. Bolis, An adaptive conjoint analysis of freight service alternatives : evaluating the maritime option 
Quaderno n. 05-01

M. Farsi, M. Filippini, An analysis of efficiency and productivity in Swiss hospitals

Quaderno n. 05-02

M. Filippini, G. Masiero, K. Moschetti, Socioeconomic determinants of regional differences in outpatient antibiotic consumption : evidence from Switzerland

Quaderno n. 06-01

M. Farsi, L. Gitto, A statistical analysis of pain relief surgical operations

Quaderno n. 06-02

M. Farsi, G. Ridder, Estimating the out-of-hospital mortality rate using patient discharge data

Quaderno n. 06-03

S. Banfi, M. Farsi, M. Filippini, An empirical analysis of child care demand in Switzerland

Quaderno n. 06-04

L. Crivelli, M. Filippini, Regional public health care spending in Switzerland : an empirical analysis

Quaderno n. 06-05

M. Filippini, B. Lepori, Cost structure, economies of capacity utilization and scope in Swiss higher education institutions

Quaderno n. 06-06

M. Farsi, M. Filippini, Effects of ownership, subsidization and teaching activities on hospital costs in Switzerland

Quaderno n. 06-07

M. Filippini, G. Masiero, K. Moschetti, Small area variations and welfare loss in the use of antibiotics in the community

Quaderno n. 06-08

A. Tchipev, Intermediate products, specialization and the dynamics of wage inequality in the US

Quaderno n. 06-09

A. Tchipev, Technological change and outsourcing : competing or complementary explanations for the rising demand for skills during the 1980s?

Quaderno n. 07-01

M. Filippini, G. Masiero, K. Moschetti, Characteristics of demand for antibiotics in primary care : an almost ideal demand system approach

Quaderno n. 07-02

G. Masiero, M. Filippini, M. Ferech, H. Goossens, Determinants of outpatient antibiotic consumption in Europe : bacterial resistance and drug prescribers

Quaderno n. 07-03

R. Levaggi, F. Menoncin, Fiscal federalism, patient mobility and the soft budget constraint : a theoretical approach 
Quaderno n. 07-04

M. Farsi, The temporal variation of cost-efficiency in Switzerland's hospitals : an application of mixed models

Quaderno n. 08-01

M. Farsi, M. Filippini, D. Lunati, Economies of scale and efficiency measurement in Switzerland's nursing homes

Quaderno n. 08-02

A. Vaona, Inflation persistence, structural breaks and omitted variables : a critical view

Quaderno n. 08-03

A. Vaona, The sensitivity of non parametric misspecification tests to disturbance autocorrelation

Quaderno n. 08-04

A. Vaona, STATA tip : a quick trick to perform a Roy-Zellner test for poolability in STATA

Quaderno n. 08-05

A. Vaona, R. Patuelli, New empirical evidence on local financial development and growth

Quaderno n. 08-06

C. Grimpe, R. Patuelli, Knowledge production in nanomaterials : an application of spatial filtering to regional system of innovation

Quaderno n. 08-07

A. Vaona, G. Ascari, Regional inflation persistence : evidence from Italy 